Olena Prokhorova,

PhD (Candidate of Pedagogical Sciences), senior lecturer, Department of Western and Eastern Languages and Methods of their Teaching, South Ukrainian National Pedagogical University named after K. D. Ushynsky, 34, Staroportofrankivska Str., Odessa, Ukraine

\title{
INTERACTIVE TECHNOLOGIES AS A COMPONENT OF TEACHING SPOKEN ENGLISH FOR SPECIFIC PURPOSES TO STUDENTS OF CHOREOGRAPHIC EDUCATION FACULTY
}

The article deals with the relevance of using the information technology called "cloud computing”, which is based on Google Apps Internet applications, in the educational process. It is noted that cloud technologies help to organize active learning process; increase the intellectual satisfaction from classes significantly; develop thinking, memory, creativity, ingenuity of students, and prepare them for professional activities. The purpose of the article is to highlight the experience of using Google Apps cloud technologies in practice of teaching English for Specific Purposes at the university. To enhance student autonomy in carrying out tasks using cloud technologies, the following methods were used: forming consciousness, collecting and recording information, feedback. It has been shown that the use of Google Apps cloud technologies in the educational process helps to create sustainable motivation of students to master professional oral speech and to form independence in learning. Google Apps and cloud services can help students of the Faculty of Choreography Education to acquire professional English speaking skills more effectively.

Keywords: interactivity, cloud technologies, speaking, independence, activation.

\section{Introduction}

The process of informatization of education has its specificity determined by resource opportunities, trends, and lack of a single approach to substantiation and formation of the ways of using the information technologies to improve the backbone elements of educational activities at universities. A promising area of using applications in the educational process is an information technology called "Cloud Computing" based on Google Apps Internet application. Google Apps cloud technology is considered to be a system of Internet applications which provides students and teachers with the tools required for effective collaboration and communication. Google Apps consist of simple software-based multimedia tools that provide interactive exchange of information (text, graphics, audio, video). The advantage of the cloud is the opportunity to organize both classroom and independent work according to the following interaction types: "a student - a group of students", "a student - a student”, “a teacher - a student". The cloud technology makes it possible to build active learning process; increase the intellectual satisfaction from classes significantly; develop thinking, memory, creativity, ingenuity of students, and prepare them for professional activities.

The use of interactive technologies in the process of learning English has been studied by a great number of domestic and foreign authors. In Ukrainian pedagogical science V. Bondarenko O. Vasylenko, R. Hryshkova, H. Zakharov, Z. Kornev focused mainly on the implementation of interactive methods in learning a foreign language. Foreign researchers W. Damon and R. Lerner dealt with the specifics of perception of information that is full of characters and linguistic structures. The main idea of the principles of learning a foreign language in the study of W. Damon and R. Lerner involved the need for applying integrated approach to learning a foreign language, which not only combines learning by heart and listening to words and their grammar constructions, but also represents the cultural meaning of the concepts used in the specific constructions [1]. The research studies of $\mathrm{M}$. Mather and M. Sutherland are dedicated to theoretical identification of emotion patterns influence on memory [2]. E. Kensinger and D. Schacter studied the issue of using interactive technologies empirically, on the basis of neuropsychological processes taking place in the cerebral cortex when exposed to emotional exciters during memorization processes [3]. J. M. Dewaele, studying the emotional aspects of learning a foreign language, found that the learning process should arouse the interest of students in the structure of a language and its nature [4].

The main difference between domestic and foreign researches is that most of Ukrainian scientists study methodology of interactive technologies implementation into the educational process, while foreign scientists analyze the impact of these technologies on the effectiveness of knowledge and skills gained. This study is an attempt to convert both approaches. Moreover, in domestic and foreign studies Google Apps cloud technologies are regarded mainly as auxiliary means of learning a foreign language. In this study, Google Apps cloud technologies will be considered as the basic ones in the learning process.

The purpose of the article is to highlight the experience of using Google Apps cloud technologies in teaching English for Specific Purposes (ESP) at the university. The main task is analyzing Google Apps cloud services, out- 
lining the specifics of their impact on the development of professional oral English of students of the Faculty of Choreographic Education.

\section{Research methods}

When working on the thesis "Preparation of Graduates of Teaching Universities for Research Activity", the teaching of the module "Information Technologies in Research Activities" [5] was studied. It covered the theoretical and practical material regarding familiarization with Google Apps information system functioning and its application in research and professional activities.

This experience was used for working with university students of first and second years of study majoring in choreographic education. The lessons aimed to form the students' need to use modern cloud technologies in learning, increase satisfaction from their work and provide them with the opportunity of self-disclosure, cognitive interest and cognitive activity.

The classes created conditions for the development of such qualities as persistence, independence for the formation of students' ESP speaking skills.

We used the following forms of work with the students: workshops, individual work, individual counseling. Technical means of studies was cloud technology from Google Apps Educational Edition (Google Apps). The students had access to educational materials, video materials for self-study; guidelines and tasks were provided using Google Sites. They were given the following tasks: creating a personal blog using Blogger; creating a social network community using Google+; creating presentations with Google Docs that enables students to process texts and spreadsheets; conducting video conferences with multiple students using Google Hangouts.

In order to determine the level of the learned material acquisition and the ability of students to use it in practice, the following methods were applied: surveys, tests, questionnaires, final presentation of the prepared project.

We used the following means for enhancing students' independence in carrying out tasks using cloud technologies: a method of forming consciousness, for which the students were acquainted with the specificity of virtual communication and Google Apps features; method of collecting and recording information, which was carried out by using the Google Apps cloud technology and collaboration on projects; method of "feedback" for increasing the quality of students' training by encouraging collaboration and conducting deeper research.

\section{Discussion}

When using cloud technologies the teacher's task was to use the Google Docs service. It provides the opportunity to supervise the students' learning activities, to review open statistics regarding their answers and create a chart of success statistics, to comment some answers in the results table. Testing time can be adjusted by limiting the time for answers. The "form" mode can be used to analyze the results of the interrogation, view a summary of the answers, and get statistics.
During the work sessions, specific situations and problems, which the future choreographers will meet in their professional activities, were actively used. All the tasks and topics were developed in accordance with the work program of the discipline "Basics of Scientific Communication in a Foreign Language" for the Faculty of Choreography Education. Here is an example of topics that were used when working with first- and second-year students:

Beginning Choreographer's Tips

Physical Requirements and Skills

Qualifications for a Choreographer

Advantages and Disadvantages of Being a Choreographer

Differences between Choreographer and Dance Instructor

Dance Training and Experience

As students solve problems related to their future work, their motivation for language learning increases.

The Internet applications used during the lessons with the first- and second-year students should be considered in details.

First, Google Docs service was used to form the students' practical skills. Creating presentations in Google Docs allowed the students to process texts and spreadsheets. Multimedia presentations provide demonstrativeness, which contributes to intersensory perception and better memorization of the material. While performing the tasks the students used various sources of information in English to complement their presentations. Creating Google Docs presentations contributed to the development of the students' creative potential and the abilities of expressing their thoughts in English.

It should be noted that Google Docs web-service provides an opportunity to leave text comments, which is an effective tool in the interaction between a student and a teacher. It provides support, for example, counseling, assistance, feedback, not just control or final evaluation.

The task "Conducting Video Conferences with Multiple People Using Google Hangouts" was offered for providing team work of two students or a student with a group of students. The task involved text message communication, collaborative work on documents, and viewing videos. It should also be noted that Google Hangouts provides a teacher with the opportunity to hold a lecture in ten groups simultaneously. If more students want to attend the lecture, each host group can rebroadcast it in other ten groups. Classes can be interactive and students can ask questions via FM microphone [6, p. 205].

It should be emphasized that the use of Google Hangouts forms the skills of collective interaction in students and improves the way of organizing the learning process so that they communicate with each other actively, exchange educational information, which promotes acquisition of knowledge, improves skills of each student. Between the communication participants optimal interaction is created, relationships peculiar to a team are 
formed; and the condition for personal success is the success of other students in one or several groups.

Secondly, the formation of skills of expressing one's thoughts is promoted by means of Google Blogger. The task was to publish interesting facts from personal experience of working with children in English and open community access to the information. Google Blogger aims to develop the ability to select information independently, evaluate it critically and present, formulate personal findings and evaluative judgments based on the proposed information.

In the process of creating personal blogs, three phases can be distinguished: "search", "filter", and "publication". Doing this task the students were supposed to learn lots of information on the chosen topic in English. The need for regular work (new notices must be published at least once a week) makes the process of students' acquisition of knowledge of specific topics continuous. Students' motivation in using blogs is explained not only by technological opportunities, but also by the fact that most of them manage their learning process themselves, being engaged in active search for information and getting comments from other people.

Blogging tasks go beyond the limits of the educational process and relationships between a teacher and a student, as long as everyone interested can assess and comment on students' works. Blogs provide the opportunity to turn a classroom into infinite international audience. The use of blogs makes it possible to implement a principle of andragogical training - immediate use of acquired knowledge for practical action [7, p. 14]. Through didactic qualities of the blogging technology students-choreographers were involved into such types of language activities as writing and reading. They formed both critical thinking skills and skills of expressing their thoughts in a foreign language.

Thirdly, we used the task "Creating Communities in Google+" to develop students' skills professional communication and form communicative readiness for dialogue with colleagues and establishing new relationships.

Creating a community in social media based on Google+ service was used for collaborative work on projects, communication and advisory support. Taking part in such groups provides an opportunity to organize joint activities with fellow students and teachers.

Google + developers indicate that "the main feature of the new network is the so-called "circles". With these circles it can be very convenient to sort all contacts from various areas". In this case, implementing Google Apps

\section{REFERENCES}

1. Damon, W., \& Lerner, R. (2008). Child and adolescent development. An advanced course. Retrieved from: https://www.researchgate.net/profile/ Jacquelynne_Eccles/publication/228017465_Development_of_A chievement_Motivation/links/0912f50b4e42f5 1119000000/Development-of-AchievementMotivation.pdf [in English]. has allowed to integrate e-mail system and the electronic publications system with a great number of technical means available for students these days, including institutional servers where educational materials available from any computer in the world via the Internet are stored and a server for storing materials prepared by students.

Thus, we can single out the following steps of using Google Apps cloud technology in the process of learning the English language:

1) designing and building a website by the teacher who uses Google Sites, which creates the possibility of online access to educational materials, namely the series of classes provided with thematic dictionaries, video materials for independent study, recommendations and goals that should be achieved;

2) creating a presentation on the chosen topic using Google Docs, which helps to process texts, spreadsheets and presentations;

3) creating a personal blog using Google Blogger. The defining feature of this task is the motivated character. The student knows not only what he/she has to do but what he/she is writing something for;

4) creating a social network community using Google+. During this phase the student may undergo a training in communicating with foreigners. In fact, at this stage communicative or communicative-role motivation is being actualized, where the student reads or writes on the topic that interests him/her;

4) conducting video conferences with other students using Google Hangouts, which provides online communication, text messaging, exchanging of documents, viewing videos and collaboration;

Control of task fulfillment by students at each stage is performed by the teacher using Google Docs. Development of surveys and questionnaires is performed in the Internet via the Google Docs cloud service, which automatically calculates the results and creates a graph of statistical data.

\section{Conclusions}

Building a virtual learning space is determined by the desire to combine existing teaching experience with new information technologies. The use of Google Apps cloud technologies in the educational process helps to create sustainable motivation of students to master professional oral speech and to form independence in learning. Google Apps and cloud services can help students of the Faculty of Choreography Education to acquire professional English speaking skills more effectively.

2. Mather, M., \& Sutherland, M. (2012). The selective effects of emotional arousal on memory. Psychological science agenda, 2. (Vols. 26). Retrieved from: http://www.apa.org/science/about/psa/2012/02/emotionalarousal.aspx [in English].

3. Kensinger, E., \& Schacter, D. (2010). Memory and emotion. Current directions in psychological science, 
4, 213-218. (Vols. 16). Retrieved from: https://www2.bc.edu/ kensinel/Kensinger_Schacter_Han dbookEmo.pdf [in English].

4. Dewaele, J. M. (2011). Reflections on the emotional and psychological aspects of foreign language learning and use. Anglistik: International journal of English studies. (pp. 23-42). Retrieved from: http://eprints.bbk.ac.uk/5096/1/Dewaele2011Anglistik.pd f [in English].

5. Prokhorova, O. V. (2014). Pidhotovka mahistrantiv pedahohichnykh universytetiv do naukovodoslidnytskoi diialnosti [Preparing undergraduates of pedagogical universities for scientific research]. Extended abstract of candidate's thesis. Kherson [in Ukrainian].

\section{ЛІТЕРАТУРА}

1. Damon W. Child and adolescent development. An advanced course [Електронний ресурс] / W. Damon, R. Lerner. - John Wiley \& Sons, Inc., 2008. - 816 p. Режим доступу: https://www.researchgate.net /profile/Jacquelynne_Eccles/publication/228017465_Dev elopment_of_Achievement_Motivation/links/ 0912f50b4e42f51119000000/DevelopmentofAchievemen t-Motivation.pdf.

2. Mather M. The selective effects of emotional arousal on memory [Електронний ресурс] / M. Mather, M. Sutherland // Psychological science agenda. - 2012. Vol. 26. - No. 2 - Режим доступу : http://www.apa.org/science/about/psa/2012/02/emotionalarousal.aspx.

3. Kensinger E. Memory and emotion [Електронний ресурс] / E. Kensinger, D. Schacter // Current directions in psychological science. - 2010. - Vol. 16. - No. 4. - P. 213-218. - Режим доступу : https://www2.bc.edu/ kensinel/Kensinger_Schacter_Han dbookEmo.pdf.

4. Dewaele J. M. Reflections on the emotional and psychological aspects of foreign language learning
6. Voronkin, O. S. (2011). Personalni navchalni merezhi v systemi dystantsiinoi osvity [Personal Learning Networks in distance education]. New information technologies in education for all: learning environment: Proceedings of the $4^{\text {th }}$ International conference. (pp. 202208). Kyiv [in Ukrainian].

7. Belov, S. A., \& Lazareva, D. G. (2011). Obuchenie studentov vuza $\mathrm{s}$ ispolzovaniem blogov kak sredstva upravleniya ikh uchebno-poznavatelnoy deyatelnostyu [Training university students using blogs as a means of managing their learning and cognitive activities]. Izvestiya Altaiskogo gosudarstvennogo universiteta - Bulletin of Altai State University, 2-2, 13-16 [in Russian].

and use [Електронний ресурс] / J. M. Dewaele // Anglistik: International journal of English studies. - 2011. - P. 23-42. - Vol. 16. - No. 4. - Р. 213-218. - Режим доступу : http://eprints.bbk.ac.uk/5096/1/Dewaele2011 Anglistik.pdf.

5. Прохорова О. В. Підготовка магістрантів педагогічних університетів до науково-дослідницької діяльності: автореферат дис. ... канд. пед. наук : 13.00.04 / О. В. Прохорова ; М-во освіти і науки України, Херсонський держ. ун-т. - Херсон, 2014. $20 \mathrm{c}$.

6. Воронкін О. С. Персональні навчальні мережі в системі дистанційної освіти / О.С.Воронкін // New information technologies in education for all: learning environment : збірник праць VI Міжнародної конференції, ITEA. - 22-23 листопада 2011p. - Київ, 2011. - С. 202-208.

7. Белов С. А. Обучение студентов вуза с использованием блогов как средства управления их учебно-познавательной деятельностью / С. А. Белов, Д. Г. Лазарева // Известия Алтайского государственного университета. - 2011. - № 2-2. - С. 13-16.

Олена Вікторівна Прохорова, кандидат педагогічних наук, стариий викладач кафедри західних та східних мов і методики їх навчання, Південноукраїнський національний педагогічний університет імені К. Д. Уиинського, вул. Старопортофранківска, 34, м. Одеса, Украӥна

\section{ІНТЕРАКТИВНІ ТЕХНОЛОГІЇ ЯК КОМПОНЕНТ НАВЧАННЯ УСНОГО АНГЛІЙСЬКОГО ПРОФЕСІЙНОГО МОВЛЕННЯ СТУДЕНТІВ ФАКУЛЬТЕТУ ХОРЕОГРАФІЧНОЇ ОСВІТИ}

У роботі розглянуто актуальність використання у навчальному процесі інформаційної технології, яка дістала назву «хмарні обчислення» (Cloud computing), що здійснюється шляхом застосування Інтернет-додатку Google Apps. Хмарні технології дозволяють побудувати активний процес навчання, суттєво збільшують інтелектуальну задоволеність від занять, розвивають мислення, пам'ять, винахідливість, кмітливість студентів, готують їх до професійної діяльності. Мета статті полягає у висвітленні досвіду використання хмарних технологій Google Apps у практиці ВНЗ під час вивчення професійної англійської мови. Основним завданням, яке ставить перед собою автор статті, полягає у тому, щоб, проаналізувавши хмарні сервіси Google Apps, окреслити специфіку їхнього впливу на успішність розвитку усного англійського професійного мовлення студентів факультету хореографічної освіти. Виділено такі види роботи з використанням зазначених хмарних технологій під час вивчення професійної англійської мови: 1) розробка веб-сайту викладачем за допомогою сервіcy Google Sites, що дає змогу забезпечити онлайн доступ до навчальних матеріалів; 2) створення студентами презентацій з обраної теми за допомогою сервісу Google Docs; 3) створення блогу в сервісі Google Blogger, що сприяє розвитку вмо- 
тивованості студентів до навчальної діяльності; 4) створення спільноти у соціальній мережі за допомогою сервicy Google+; 5) проведення відео-конференцій з іншими студентам за допомогою Google Hangouts. Для aктивізації самостійності студентів під час виконання завдань за допомогою хмарних технологій були використані наступні методи: метод формування свідомості, метод збору та реєстрації інформації, метод «зворотний зв'язок». Показано, що застосування хмарних технологій Google Apps у процесі навчання сприяє створенню стійкої мотивації студентів до оволодіння усним професійним мовленням та активізації самостійності під час навчання. Констатовано, що Інтернет-додаток Google Apps та його хмарні сервіси, що у нього входять, можуть допомогти студентам факультету хореографічної освіти більш ефективно опановувати навички англійського професійного мовлення.

Ключові слова: інтерактивність, хмарні технології, усне мовлення, самостійність, активізація.

Reviewed by Doctor of Pedagogy, prof. T. Yablonska

Submitted on March, 16, 2017

UDC: 378:373.2:004

DOI: https://doi.org/10.24195/2414-4665-2017-4-10

\author{
Oksana Chekan, \\ PhD (Candidate of Pedagogical Sciences), senior lecturer, \\ Khrystyna Barna, \\ PhD (Candidate of Pedagogical Sciences), senior lecturer, \\ Viktoriia Ivanova, \\ PhD (Candidate of Psychological Sciences), senior lecturer, \\ Department of Theory and Methodology of Preschool Education, \\ Mukachevo State University, \\ 26, Uzhhorodska Str., Mukachevo, Ukraine
}

\title{
FORMATION OF FUTURE NURSERY TEACHERS' PROFESSIONAL COMPETENCE BY MEANS OF INFORMATION AND COMMUNICATIONS TECHNOLOGIES
}

The article deals with the stages of future nursery teachers' professional competence formation by means of information and communications technologies. Future nursery teachers' readiness to use information and communications technologies in their work is an integrated indicator which is manifested in stable associative bonds between professional competencies and models of their realization with the use of information and communications technologies; in acquiring information and communication technologies which are essential for effective fulfillment of basic functional operations in the information environment of a modern preschool educational institution; in the ability to interpret all tasks of educational and commutative processes of a preschool institution through available functional components of external and internal information environments. The following stages of future nursery teachers' professional competence formation by means of information and communications technologies have been distinguished: cognitive and enriching, productive and active, creative and informational. The formation of future nursery teachers' professional competence based on the application of information and communications technologies together with the use of microteaching methodology for the formation of associative connections can be assessed according to the following criteria: cognitive-informational, activity-informational, managerial-informational.

Keywords: information and communications technology, professional competence, computer-oriented technology.

\section{Introduction}

The task of higher education in the period of society informatization is the training of professionals able to use modern innovative technologies at the necessary level. According to the Law of Ukraine "On Education", the purpose of education is comprehensive development of a personality as the greatest value of the society, develop- ment of person's talents, mental and physical abilities, education of high moral qualities, formation of citizens able for conscious social selection, enrichment of intellectual, creative and cultural potential of nation on this basis, increasing of educational level, providing of national economy with qualified specialists. 